\title{
Study on response of water-table aquifer under shallow, deep and
}

\section{high-intensity exploitation}

\author{
SUN Xueyang ${ }^{1,2}$, LIU Ziqiang ${ }^{2}$,LI Cheng ${ }^{1,3}$, LIU Liangdong ${ }^{2}$, KOU Guigui $^{2}$,LI \\ Pengqiang $^{2}$
}

\begin{abstract}
(1.Key Laboratory of Mine Geological Hazards mechanism and Control,Shaanxi Institute of Geological Survey,710054,China;2.Xi'an University of Science and Technology, School of Geology and Environment, Xi'an 710054, China;3.Geological Survey Center of Shaanxi Institute of Geological Survey,710054,China)
\end{abstract}

Keywords: Yushenfu Mining Area; numerical simulation; solid-liquid coupling; response law Abstract: The depth of coal seam buried in Yushenfu mining area is shallow, and there is inevitable contradiction between the mining activities of high strength coal seam and the protection of aquifers. Therefore, it is very important to study aquifer's response law to coal seam mining for scientific mining of coal seam in this area. Therefore, based on the present situation of 5201 working face of a mine in Shenfu mining area, this paper will study the variation law of aquifer when the mining height is $6 \mathrm{~m}$ and the width of working face is $100 \mathrm{~m}$ by using FLAC3D solid-liquid coupling numerical simulation method.The results show that :The maximum response range of aquifer in the inclination direction and trending direction is $393 \mathrm{~m}$ and $964 \mathrm{~m}$ respectively, and the maximum water level is drop $7.7 \mathrm{~m}$.

\section{INTRODUCTION}

The environmental protection of Jurassic coal field in Northern Shaanxi attracts much attention for the shallowly buried coal seam and fragile surface ecological environment. Once the coal mining causes the seepage and drop of the water level of the aquifer of Salawusu group, it will have a huge and irreversible impact on the ecological environment of the surface ${ }^{[1-3]}$. Rational utilization of Yushenfu groundwater resources, located on the edge of the Maowusu desert, poor groundwater resources, is the key to coalfield development. The groundwater in the Salawusu group in this area is a reliable water supply base and a source of severe deterioration of the engineering geological conditions as well as a major hazard to the mine shaft abandonment and submerged equipment caused by quicksand collapse into the mine.Therefore, in this paper, the influence law of coal mining activity on the aquifer is researched by numerical simulation when the mining thickness is $6 \mathrm{~m}$ and the width of working face is $100 \mathrm{~m}$, which will provide guidance for the green mining of coal resources in Shenfu Mining Area.

\section{EXPERIMENTAL DESIGN}

During the design of the model, 300m protection coal pillars are reserved for each boundary, therefore, the final size of the model is: length $\times$ width $\times$ height $=1200 \mathrm{~m} \times 700 \mathrm{~m} \times 243 \mathrm{~m}$, in which the thickness of coal seam is $6 \mathrm{~m}$, the thickness of coal seam floor is $8 \mathrm{~m}$, the thickness of aquifer is 
$8 \mathrm{~m}$ and aquifer from the surface is $8 \mathrm{~m}$. The pore water pressure is applied to the aquifer,which are submersible aquifers, according to the gradient of $1 \times 10^{4} \mathrm{pa} / \mathrm{m}$. The pore water pressure at the bottom of the aquifer is $8 \times 104 \mathrm{pa}$, and the pore water pressure at the top is 0Pa. Cell division: The horizontal cell division specifications for the $20 \mathrm{~m} \times 20 \mathrm{~m}$. And in the vertical direction, the division height be controlled at $15 \mathrm{~m} \sim 20 \mathrm{~m}$ depending on the thickness of the rock layer,which ensures the uniformity of model meshing. Experimental model shown in Fig.1. On the other hand, in order to more accurately simulate the variation law of aquifers after mining, the grid change ratio of loess layer below the aquifer is set to 0.8 to raise the aquifer water level Decrease depth of precision especially. During the simulation process, the pore water pressure will change when water is filled in the rock formation. So, the pore water pressure increase zone is taken as the judgment basis for the water level drop of the aquifer. Excavation process each step forward 60m, calculated 1500 times, 10 minutes to complete the excavation process. Excavation process is divided into 10 steps to complete, each step pushing forward $60 \mathrm{~m}$ and calculated 1500 times.

Table 1. Numerical experiment generalization model of physical and mechanical parameters of coal and rock

\begin{tabular}{|c|c|c|c|c|c|c|c|c|}
\hline Sequence & Lithology & $\begin{array}{l}\text { Strata thickness } \\
(\mathrm{m})\end{array}$ & $\begin{array}{c}\text { Bulk } \\
\text { density } \\
\left(\mathrm{KN} / \mathrm{m}^{3}\right)\end{array}$ & $\begin{array}{c}\text { Elasticity } \\
\text { Modulus } \\
(\mathrm{MPa})\end{array}$ & $\begin{array}{c}\text { Compressive } \\
\text { strength } \\
(\mathrm{MPa})\end{array}$ & $\begin{array}{c}\text { internal } \\
\text { friction angle } \\
\left({ }^{\circ}\right)\end{array}$ & $\begin{array}{l}\text { Poisson } \\
\text { ratio }\end{array}$ & $\begin{array}{c}\text { Cohesive } \\
(\mathrm{MPa})\end{array}$ \\
\hline 1 & drift-sand & 8 & 19.2 & 69 & 0.8 & 30 & 0.31 & 0.069 \\
\hline 2 & Aquifer & 8 & 19.2 & 69 & 0.8 & 30 & 0.31 & 0.069 \\
\hline 3 & Loess & 51 & 16.86 & 1000 & 1.59 & 30.9 & 0.31 & 0.069 \\
\hline 4 & laterite & 33 & 18.23 & 800 & 2.12 & 30.5 & 0.35 & 0.086 \\
\hline 5 & Sandstone & 21 & 24.6 & 4000 & 30.0 & 42 & 0.19 & 3.27 \\
\hline 6 & mudstone & 15 & 24.89 & 1000 & 20.0 & 28 & 0.13 & 5.8 \\
\hline 7 & Sandstone & 11 & 24.6 & 4000 & 30.0 & 42 & 0.19 & 3.27 \\
\hline 8 & mudstone & 1 & 24.89 & 1000 & 20.0 & 28 & 0.13 & 5.8 \\
\hline 9 & Sandstone & 31 & 24.6 & 4000 & 30.0 & 42 & 0.19 & 3.27 \\
\hline 10 & $\begin{array}{c}\text { Feldspar quartz } \\
\text { sandstone }\end{array}$ & 27 & 24.89 & 1000 & 20.0 & 28 & 0.13 & 5.8 \\
\hline 11 & pelitic siltstone & 2 & 25.2 & 4300 & 74.5 & 43 & 0.18 & 3.67 \\
\hline 12 & mudstone & 6 & 24.89 & 1000 & 20.0 & 28 & 0.13 & 5.8 \\
\hline 13 & Fine grained & 16 & 25.0 & 6000 & 87.6 & 42 & 0.19 & 3.27 \\
\hline 14 & caol & 5 & 13.5 & 1000 & 24.5 & 38 & 0.28 & 2.13 \\
\hline 15 & pelitic siltstone & 8 & 25.2 & 4300 & 74.5 & 43 & 0.18 & 3.67 \\
\hline
\end{tabular}


Table 2. rock stratum hydrologic parameters of numerical experiment generalizing model

\begin{tabular}{ccc|ccc}
\hline lithology & $\begin{array}{c}\text { Permeability } \\
(\mathbf{c m} / \mathbf{s})\end{array}$ & Po rosity & lithology & $\begin{array}{c}\text { Permeability } \\
(\mathbf{c m} / \mathbf{s})\end{array}$ & porosity \\
\hline drift-sand & & 0.3 & Sandstone & $1.3 \mathrm{e}-6$ & 0.05 \\
Aquifer & $2.7 \mathrm{e}-3$ & Feldspar quartz & $5.0 \mathrm{e}-9$ & 0.09 \\
Loess & $8.4 \mathrm{e}-5$ & 0.4 & sandstone & 0.077 \\
laterite & $1.4 \mathrm{e}-6$ & 0.096 & pelitic siltstone & $2.3 \mathrm{e}-6$ & 0.05 \\
Sandstone & $1.3 \mathrm{e}-6$ & 0.103 & mudstone & $1.08 \mathrm{e}-9$ & 0.081 \\
mudstone & $1.08 \mathrm{e}-9$ & 0.05 & Fine grained sandstone & $2.3 \mathrm{e}-6$ & 0.07 \\
Sandstone & $1.3 \mathrm{e}-6$ & 0.05 & caol & $8.8 \mathrm{e}-6$ & 0.077 \\
mudstone & $1.08 \mathrm{e}-9$ & 0.05 & pelitic siltstone & $2.3 \mathrm{e}-6$ & 0.07 \\
\hline
\end{tabular}

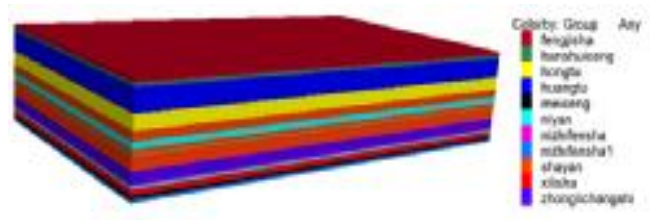

Fig.1. FLAC3D numerical simulation model diagram

\section{EXPERIMENTAL SIMULATION}

When the working face is advanced to $240 \mathrm{~m}$, the pore water pressure and the development of water flowing fractured zone are shown in Fig.2. The height of the plastic zone is $92 \mathrm{~m}$, getting the propotion of water flowing fractured zone height and caving thickness is 15.3. At this time, the distribution range of high pore water pressure in aquifers just above the goaf has been expanded in the vertical direction vertical. Based on this analysis, when the excavation started from $180 \mathrm{~m}$ to $240 \mathrm{~m}$, the aquifer began to be impacted. By analyzing the Fig.2a, the area with high pore water pressure concentration is located directly above the working face and the influence length is from $92 \mathrm{~m}$ in front of the working face to $329 \mathrm{~m}$ behind the working face. that is the influence length on the trending direction of coal mining face is $461 \mathrm{~m}$. In the inclination direction of the the working face, the center position of the section analysis is made by the high pore water pressure concentrated area (section shown in Fig.2c). The total length of influence range is $173 \mathrm{~m}$.In the process of simulation, the pore water pressure in aquifers is a fixed value. When monitoring water level, $70000 \mathrm{~Pa}$ pore water pressure isosurface is selected as the reference level of water level monitoring. Based on that, the maximum drawdown value of water level is $1.02 \mathrm{~m}$. 


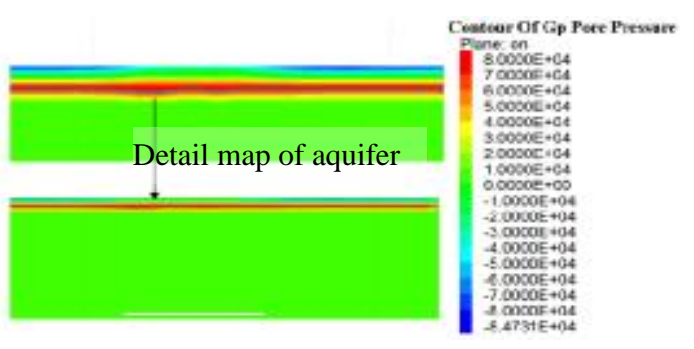

a. Pore water pressure distribution

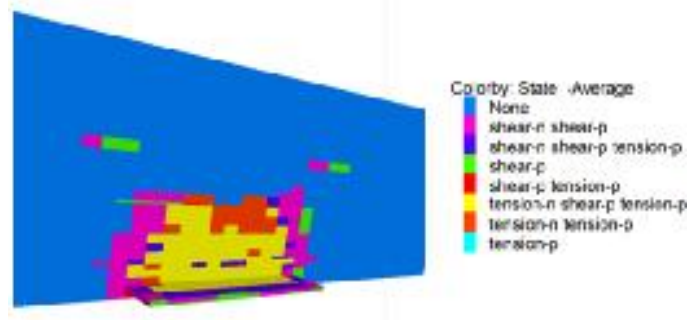

b. Plastic zone distribution

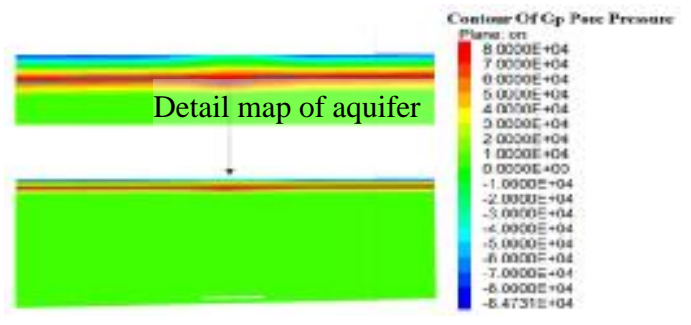

c. Distribution diagram of pore water pressure in inclination direction

Fig. 2 The pore water pressure and the plastic zone distribution map of the working face pushed to $240 \mathrm{~m}$

When the working face is pushed to $480 \mathrm{~m}$, the pore water pressure and the development of water flowing fractured zone are shown in Fig.3. The development height of the plastic zone is $162.0 \mathrm{~m}$, and the propotion of water flowing fractured zone height and caving thickness is 27 . The image can be observed that the water flowing fractured zone is close to the aquifer. At the same time, the loess layer under the bottom of aquifer also produced the pore water pressure distribution both sides of Open-off cut and working face. The center position of the high pore water pressure concentrated area of aquifer is located to the near side of the working face. And the length of influence is $204.6 \mathrm{~m}$ in front of the working face to $636.0 \mathrm{~m}$ behind working face. Namely, the length of impact on the trending direction is $840.6 \mathrm{~m}$. The high pore water pressure area, in loess layer, is located at the rear of working face $100 \mathrm{~m}$ to $65 \mathrm{~m}$ in front of working face (namely,the total length is $165 \mathrm{~m}$ ), and $28 \mathrm{~m}$ behind Open-off cut (Goaf side) to $92 \mathrm{~m}$ in front of Open-off cut (namely,the total length $120 \mathrm{~m}$ ), which is connected with the aquifer. In the inclination direction of the the working face, the center position of the section analysis is made by the high pore water pressure concentrated area(section shown in Fig.3c). According to the analysis of figure, the response range of pore water pressure to coal seam mining extends $196 \mathrm{~m}$ and $187 \mathrm{~m}$ from the center to the sides of the working face, and the distribution tends to be symmetrical with the total impact length of $383 \mathrm{~m}$. According to the analysis of the $70000 \mathrm{~Pa}$ pore water pressure equivalent surface, the maximum 
drop depth of the water level is $4.9 \mathrm{~m}$. The distance, between the high pore water pressure of the loess layer bottom and the $70000 \mathrm{~Pa}$ pore water pressure equivalent surface, is $50.17 \mathrm{~m}$. After further comparative analysis, because mining impact on the overlying soil layer had a disturbance, changing its permeability, to increase the permeation amount of the aquifer of Salawusu group, and cause the water level further reduce.

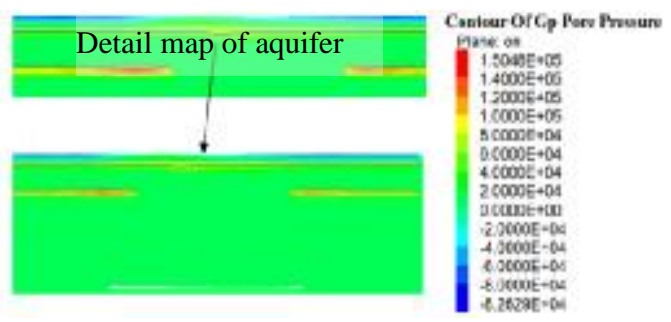

a. Pore water pressure distribution

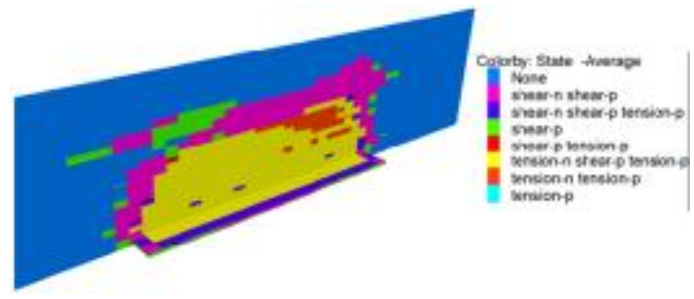

b. Plastic zone distribution

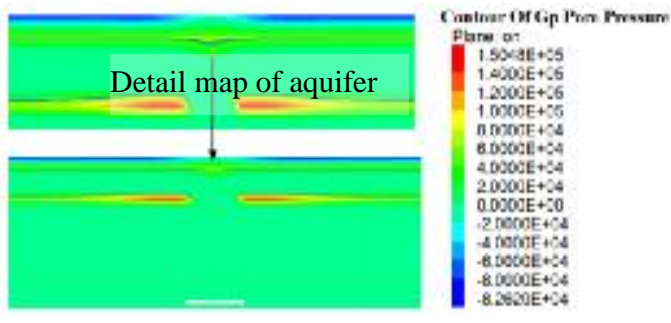

c. Distribution diagram of pore water pressure in inclination direction

Fig.3 The pore water pressure and the plastic zone distribution map of the working face to $480 \mathrm{~m}$

When the working face is advanced to $600 \mathrm{~m}$, the pore water pressure and the development of water flowing fractured zone are shown in Fig.4. The development height of the plastic zone is $164.0 \mathrm{~m}$, and the propotion of water flowing fractured zone height and caving thickness is 27.3. It is found by comparison that the height of the plastic zone has stabilized. The high pore water pressure zone still occurs directly above the mining face at the bottom of the loess layer, affecting $208 \mathrm{~m}$ in front of the working face and $206.9 \mathrm{~m}$ behind the working face, which the total length in the trending direction of working face is $414.9 \mathrm{~m}$. The change trend of water level in aquifer is the same as that of the high pore water pressure at the bottom of loess layer. The $70000 \mathrm{~Pa}$ pore water pressure isosurface had a "concave shape" increase above the mining face, and the water level drop value of the aquifer was judged to be $7.7 \mathrm{~m}$. In the inclination direction of the the working face, the center position of the section analysis is made by the high pore water pressure concentrated area(section shown in Fig.3c). From the diagram analysis, the response range of pore water pressure 
to the coal seam mining is $198 \mathrm{~m}$ and $195 \mathrm{~m}$ from the center to the both sides of the working face. Compared with the excavation to $480 \mathrm{~m}$, the influence of coal mining on the SalaWusu aquifer has stabilized.

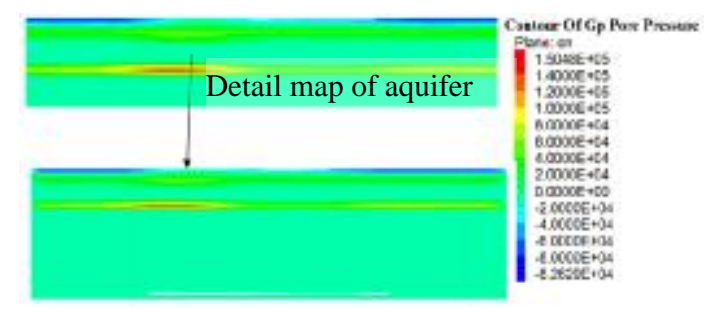

a. Pore water pressure distribution

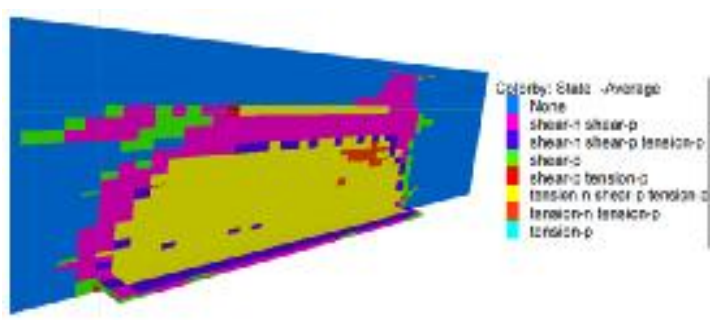

b. Plastic zone distribution

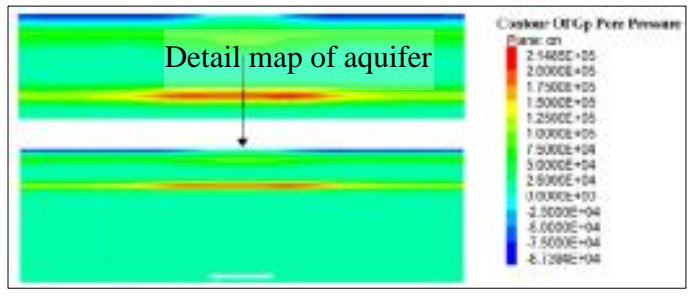

c. Distribution diagram of pore water pressure in inclination direction

Fig.4 The pore water pressure and the plastic zone distribution map of the working face to $600 \mathrm{~m}$

\section{CONCLUSION}

1. When the thickness of coal seam is $6 \mathrm{~m}$ and the width of working face is $100 \mathrm{~m}$, the maximum height of water flowing fractured zone development is $164.0 \mathrm{~m}$, the propotion of water flowing fractured zone height and caving thickness is 27.3. And the water flowing fractured zone is not conductive in aquifer. When the working face is pushed to $480 \mathrm{~m}$, the plastic zone tends to be stable.

2. When the coal seam is mined to $180 \mathrm{~m}$, the influence on the aquifer is not obvious; the pore water pressure is basically distributed in the aquifer.

3 . When the coal seam is mined to $240 \mathrm{~m}$, pore water pressure began to show a "concave shape" growth model. The lowest point of the "concave shape " type moves along with the working face moves forward. When the working face is mined to $600 \mathrm{~m}$, the value of the lower concavity reaches the maximum of $7.7 \mathrm{~m}$.

4. In the inclination direction of the working face, the area of the aquifer affected by the coal mining 
trend to be stable when the working face is pushed to the $480 \mathrm{~m}$, and the impact range of the excavation to $600 \mathrm{~m}$ is $393 \mathrm{~m}$. In the trending direction of the working face, the influence range of coal mining on aquifer is increasing along with the continuous advancing of coal mining face. The influence range is $208 \mathrm{~m}$ in front of working face to $156 \mathrm{~m}$ front of Open-off cut, and the total length is $964 \mathrm{~m}$.

\section{ACKNOWLEDGEMENT}

This paper was supported by the National Natural Science Foundation of China(41272388) and the Research project of .Key Laboratory of Mine Geological Hazards mechanism and Control,Shaanxi Institute of Geological Survey(KF2017-14)

\section{REFERENCES}

[1]FAN Li-min,MA Xiong-de,JI Rui-jun.Progress in engineering practice of water-preserved coal mining in western eco-environment frangible area[J]. Journal of China Coal Society, 2015, 40(8):1711-1717.

[2]WANG Shuang-ming, FAN Li-min,MA Xiong-de. Coal development and ecological water level protection in ecological fragile area [J]. China Mining Magazine, 2010(19):212-216.

[3] Ma Xiongde, Fan Limin, Zhang Xiaotuan, et al. Driving force analysis for water and wetlands evolution at Yushenfu mining area $[\mathrm{J}]$. Journal of China Coal Society, 2015, 40(5) : 1126-1133.

[4] MA Liqiang, ZHANG Dongsheng, Qiao Jinli, et al.. Physical simulation of water crack distribution characteristics in overlying strata under coal mining conditions [J]. Journal of Liaoning Technical University（Natural Science）,2008,27(5):649-652.

[5] Ju Jinfeng, Xu Jialin, Zhu Weibing. Storage capacity of underground reservoir in the Chinese western water-short coalfield [J]. Journal of China Coal Society, 2017, 42(2):381 - 387. 